\title{
What is new in iron overload?
}

\author{
Christiane Vermylen
}

Received: 22 May 2007 / Accepted: 30 August 2007 / Published online: 26 September 2007

(C) Springer-Verlag 2007

\begin{abstract}
Children with severe chronic hemolytic anemia or congenital erythroblastopenia are transfusion dependent. Long-term transfusion therapy prolongs life but results in a toxic accumulation of iron in the organs. The human body cannot actively eliminate excess iron. Therefore, the use of a chelating agent is required to promote excretion of iron. So far, iron chelation has been done by subcutaneous infusion of deferoxamine given over 10 h, 5-6 days per week. Compliance is poor and chelation often insufficient. Ferritin measurements and sometimes liver biopsies are used to evaluate the iron burden in the body. At the present time, new iron chelators that can be given orally are available. Furthermore, magnetic resonance imaging (MRI) assessment of tissue iron is a noninvasive and highly reproducible method, which is able to quantitate organ iron burden. In conclusion, iron overload can be measured more accurately with noninvasive methods such as MRI. Deferasirox is a once-daily oral therapy for treating transfusional iron overload, which improves patient compliance and quality of life.
\end{abstract}

Keywords Iron overload · Diagnosis $\cdot$ Chelators

$\begin{array}{ll}\text { Abbreviations } \\ \text { MRI } & \text { magnetic resonance imaging } \\ \text { LIC } & \text { liver iron content } \\ \text { SQUID } & \text { superconducting quantum interference device }\end{array}$

C. Vermylen $(\bowtie)$

Université Catholique de Louvain,

Cliniques Universitaires Saint Luc,

Avenue Hippocrate 10,

B 1200 Brussels, Belgium

e-mail: vermylen@pedi.ucl.ac.be

\section{Introduction}

Children suffering from severe chronic hemolytic anemia such as $\beta$-thalassemia, or congenital erythroblastopenia are at risk of developing severe iron overload. Regular blood transfusions are potentially life saving. However, every single transfusion of one unit of blood brings $200 \mathrm{mg}$ of iron into the body of the recipient. Patients receiving $3 \mathrm{U}$ every 4 weeks ( $39 \mathrm{U}$ per year) will accumulate $7.8 \mathrm{~g}$ of iron by the end of the year, in addition to the amount absorbed by the gut. The human body has no mechanism for active excretion of excess iron. Repeated transfusions lead to elevated iron levels that result in major organ damage. Excess iron is deposited largely in the liver, spleen, myocardium, and several endocrine organs. In young patients, growth and maturation is slowed, and in all age groups, liver disease, diabetes mellitus, and other complications develop. Once the body's storage capacity is exceeded, free iron catalyses the formation of highly reactive hydroxyl radicals, which cause membrane damage and protein denaturation. This process leads to tissue damage and ultimately to significant morbidity and mortality [3].

\section{Measuring iron levels}

\section{(Table 1)}

There are several methods of assessing body iron load. As $90 \%$ of excess iron is deposited in the liver, most techniques focus on measuring liver iron levels, and it is widely accepted that liver iron content (LIC) provides an accurate measure of whole-body iron concentration. The invasive nature of the liver biopsy means that other markers such as serum ferritin levels are frequently employed. Other 
Table 1 Comparison of methods for evaluating iron overload

\begin{tabular}{lllll}
\hline & Invasive & Cost & Limitation & Validation \\
\hline Ferritin & No & Low & $\begin{array}{c}\text { Infection/ } \\
\text { inflammation }\end{array}$ & Yes \\
LIC & Yes & Median & $\begin{array}{l}\text { Fibrosis/cirrhosis } \\
\text { NQt easily available }\end{array}$ & Yes \\
SQUID & No & High & Not \\
MRI & No & High & Dedicated person & Yes
\end{tabular}

LIC liver iron content, SQUID superconducting quantum interference device, $M R I$ magnetic resonance imaging

approaches using biomagnetic susceptometry and magnetic resonance imaging (MRI) are also being assessed in order to identify an accurate, low-risk, and convenient approach to assessing patient iron status.

\section{Ferritin}

Serum ferritin is easily measured using a commercially available kit. A ferritin constantly below 2,500 mg/l has been shown to reduce the risk of cardiac complications, but a target value of $1,000 \mathrm{mg} / \mathrm{l}$ is recommended. Factors such as inflammation, ascorbate status, and hepatitis can affect serum ferritin levels. Therefore, results should be interpreted with caution and a trend in the evolution of serial measurements is a better index than day-to-day variation. In patients with transfusion-dependent diseases, chelation should be initiated after 10-20 blood transfusions or when ferritin level rises above $1,000 \mathrm{mg} / \mathrm{l}$.

\section{Liver biopsy}

LIC measurement is the most accurate method for assessing body iron (Fig. 1). It also provides information about the severity of the liver disease [8]. Liver samples can be obtained by percutaneous or transjugular access. LIC measurement from a needle biopsy has been associated with a coefficient of variation of less than $10 \%$ in livers with no advanced disease. However, it has been shown that variability can be much higher in fibrotic and cirrhotic livers. Values of LIC are expressed as milligrams of iron per gram of dry liver weight.

Liver biopsy is an invasive technique that is associated with some pain and at risk of hemorrhage and infection. It is not indicated for routine assessment.

Superconducting quantum interference device (SQUID)

SQUID is capable of measuring very small changes in magnetic flux. Iron stored as ferritin and hemosiderin is the only relevant paramagnetic material in the human body. The magnitude of paramagnetic response is directly related

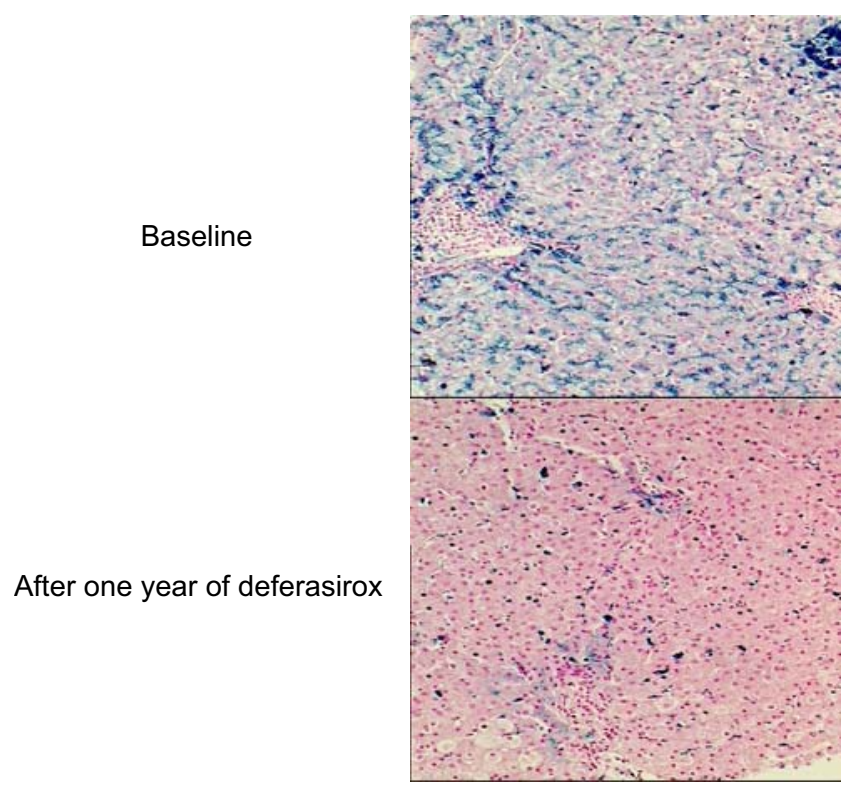

Fig. 1 Liver biopsy (Perls stain): iron deposits are in blue. Courtesy of B. Turlin, Pathology Department, University Hospital of Rennes

to the amount of iron in a certain volume of tissue. This is a noninvasive method, with a linear correlation with LIC assessed by biopsy. However, equipment availability is extremely limited [6].

\section{Magnetic resonance imaging (MRI)}

MRI measures tissue iron concentration indirectly by detecting the paramagnetic influences of storage iron (ferritin and hemosiderin) on proton resonance behavior. With MRI, the transmitted signal is a microwave, which excites water protons in the body to higher magnetic energy states. As these water protons relax back to the unexcited state, they emit microwaves that are received and interpreted by the scanner. Iron deposits act like little magnets when placed in a strong magnetic field, disrupting coherence among the protons and darkening the image more quickly (Fig. 2) [13]. LIC determined using MRI shows excellent correlation with that obtained from liver biopsy. Furthermore, MRI has the ability to evaluate the entire organ and gives more accurate measurement of LIC, particularly in patients with heterogeneous iron content (Fig. 3). It requires a dedicated imaging method and equipment operator [13].

Iron chelation therapy

Within 1-2 years of initiation of regular blood transfusions, iron starts to accumulate in the body. The use of a chelating agent then becomes mandatory [6]. At the present time, three different therapies are available (Table 2). 


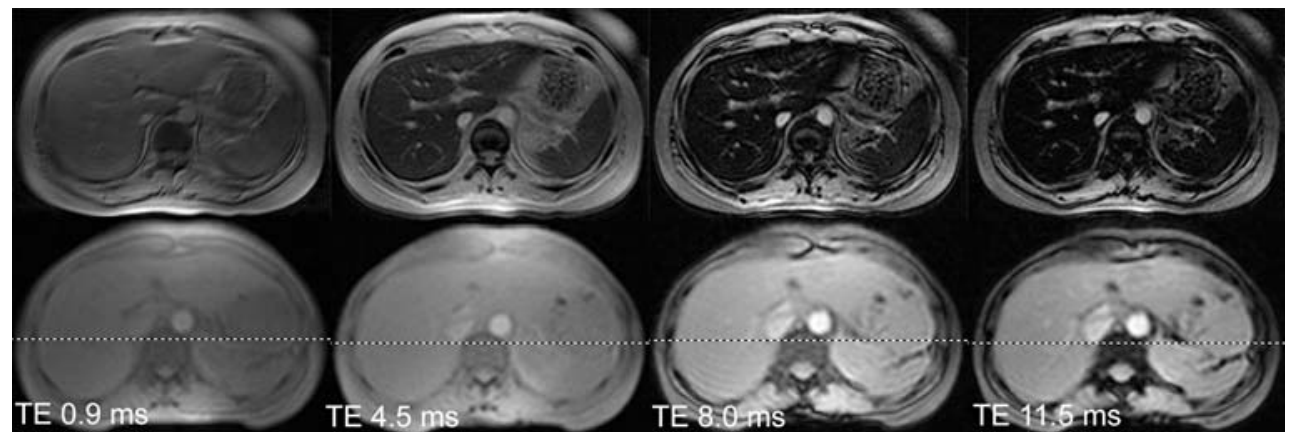

Fig. 2 Gradient echo images of liver collected by J. Wood [13] at four different echo times. The top four images were collected from a patient having a liver iron of $6 \mathrm{mg} / \mathrm{g}$. The bottom four images were collected

Deferoxamine mesylate (Desferal) is the current standard for iron chelation therapy. The long-term efficacy of this approach has been demonstrated, limiting organ damage and preventing premature death. Deferoxamine has a very short half-life in plasma (5-10 $\mathrm{min})$. Therefore, deferoxamine is administered parenterally, either subcutaneously 8-12 h a day at least 5 days a week, or intravenously, through a Port-a-Cath for continuous infusion. Low compliance with the prolonged subcutaneous administration is the main reason of ineffective treatment. Toxic side effects such as auditory, ocular, and neurotoxic abnormalities are also drawbacks in the therapy.

Deferiprone (Ferriprox) is one of the hundreds of oral chelators that have been tested. It was shown to have comparable efficacy to subcutaneous deferoxamine. It has been used as a monotherapy or in combination with deferoxamine [7, 9]. It increases urinary excretion of iron and is more effective than deferoxamine in the removal of excess iron from the heart, as shown from MRI T2* studies $[1,9,10,11]$. Deferiprone and its iron complex are cleared from the plasma with a half-life of 47-134 min. Therefore, it should be taken three times a day. The major toxic side effects are agranulocytosis, musculoskeletal and joint pains, gastric intolerance, and zinc deficiency. Those side effects are considered to be reversible. The combination of

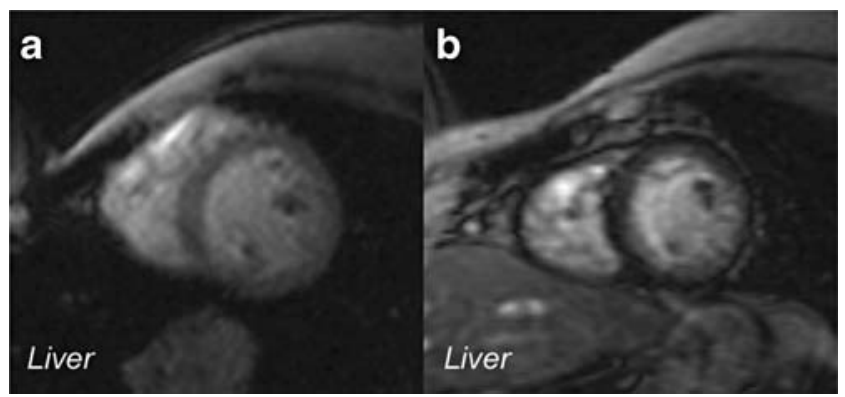

Fig. 3 Gradient echo imaging illustrating discordant iron loading of the liver and heart. a Heavy liver iron loading (dark tissue) with heart sparing image. b Heavy cardiac iron loading with no liver deposition. From [13] from a normal volunteer. All images darken as the echo time (TE) lengthens, but the iron-heavy tissue darkens faster. The half-life of this process is called $\mathrm{T} 2 *$ and the rate is called $\mathrm{R} 2 *(\mathrm{R} 2 *=1,000 / \mathrm{T} 2 *)$

deferoxamine and deferiprone is most effective when used in the following way: deferiprone ( $80-110 \mathrm{mg} / \mathrm{kg}$ per day) during the day and deferoxamine (40-60 $\mathrm{mg} / \mathrm{kg}$ per day) at least 3 nights a week. No new toxic effects have been reported for the combination.

Deferasirox (Exjade) has been tested recently in clinical trials $[2,3,12]$. Its long half-life makes it suitable for oncedaily oral administration. Efficacy at a dose of 20-30 mg/ $\mathrm{kg}$ per day is at least equivalent to that of deferoxamine ( $\geq 35 \mathrm{mg} / \mathrm{kg}$ per day 5 days weekly) in a subgroup of patients with higher hepatic iron burdens. The most common toxic side effects are skin rash, increase in transaminases and creatinine, and gastrointestinal symptoms such as nausea, vomiting, diarrhea, and abdominal pain. The skin rash and gastrointestinal symptoms tend to decrease spontaneously with time and an increase in creatinine may require a dose adjustment. The increase in transaminases is usually linked to an insufficient dose of deferasirox and an increase in the hepatic iron overload. A higher dose of deferasirox will result in an improvement in transaminases.

\section{Discussion}

Chronic iron overload due to blood transfusions leads to significant morbidity and early mortality unless adequate chelation therapy is administered. Deferoxamine is the reference chelation therapy, but compliance to the treatment is often poor because it must be administered by prolonged subcutaneous or intravenous infusion. Oral chelators are now available: Deferasirox has the advantage of being administered once daily, with a low toxicity profile. Furthermore, its cost effectiveness has also been demonstrated [5]. MRI has emerged as the dominant technique by which to evaluate iron overload because of its sensitivity, reproducibility, and ability to image multiple organs in the body during a single imaging session. 
Table 2 Comparison between iron chelators (adapted from [4])

\begin{tabular}{|c|c|c|c|}
\hline Characteristics & $\begin{array}{l}\text { Deferoxamine } \\
\text { (Desferal) }\end{array}$ & $\begin{array}{l}\text { Deferiprone } \\
\text { (Ferriprox) }\end{array}$ & $\begin{array}{l}\text { Deferasirox } \\
\text { (Exjade) }\end{array}$ \\
\hline $\begin{array}{l}\text { Route of } \\
\text { administration }\end{array}$ & $\begin{array}{l}\text { Subcutaneous or } \\
\text { intravenous }\end{array}$ & Oral & Oral \\
\hline Half-life & $20 \mathrm{~min}$ & $2-3 \mathrm{~h}$ & $8-16 \mathrm{~h}$ \\
\hline $\begin{array}{l}\text { Routes of iron } \\
\text { excretion }\end{array}$ & Urine/stool & Urine & stool \\
\hline Dose range & $20-60 \mathrm{mg} / \mathrm{kg}$ per day & $50-60 \mathrm{mg} / \mathrm{kg}$ per day & $20-30 \mathrm{mg} / \mathrm{kg} /$ day \\
\hline \multirow[t]{4}{*}{$\begin{array}{l}\text { Guidelines for } \\
\text { monitoring } \\
\text { therapy }\end{array}$} & $\begin{array}{l}\text { Audiometry and } \\
\text { eye exams annually }\end{array}$ & $\begin{array}{l}\text { Complete blood count } \\
\text { weekly; ALT level } \\
\text { monthly for first } \\
3-6 \text { months then every } \\
6 \text { months }\end{array}$ & $\begin{array}{l}\text { Serum creatinine level } \\
\text { monthly; ALT level monthly }\end{array}$ \\
\hline & Serum ferritin & Serum ferritin & Serum ferritin \\
\hline & $\begin{array}{l}\text { Assessment of liver } \\
\text { iron annually }\end{array}$ & $\begin{array}{l}\text { Assessment of liver } \\
\text { iron annually }\end{array}$ & $\begin{array}{l}\text { Assessment of liver } \\
\text { iron annually }\end{array}$ \\
\hline & $\begin{array}{l}\text { Assessment of } \\
\text { cardiac iron } \\
\text { annually after } \\
10 \text { years of age }\end{array}$ & $\begin{array}{l}\text { Assessment of cardiac } \\
\text { ron annually after } \\
10 \text { years of age }\end{array}$ & $\begin{array}{l}\text { Assessment of cardiac } \\
\text { iron annually after } \\
10 \text { years of age }\end{array}$ \\
\hline \multirow[t]{4}{*}{ Advantages } & $\begin{array}{l}\text { Long-term } \\
\text { experience }\end{array}$ & Orally active & Orally active \\
\hline & $\begin{array}{l}\text { Effective in } \\
\text { maintaining normal } \\
\text { or near-normal iron } \\
\text { stores }\end{array}$ & $\begin{array}{l}\text { Safety profile well } \\
\text { established }\end{array}$ & Once-daily administration \\
\hline & $\begin{array}{l}\text { Reversal of cardiac } \\
\text { disease with } \\
\text { intensive therapy }\end{array}$ & $\begin{array}{l}\text { Enhanced removal of } \\
\text { cardiac iron }\end{array}$ & $\begin{array}{l}\text { Demonstrated equivalency } \\
\text { to deferoxamine at } \\
\text { higher doses }\end{array}$ \\
\hline & $\begin{array}{l}\text { May be combined } \\
\text { with deferiprone }\end{array}$ & $\begin{array}{l}\text { May be combined with } \\
\text { deferoxamine }\end{array}$ & $\begin{array}{l}\text { Trials in several } \\
\text { hematologic disorders }\end{array}$ \\
\hline \multirow[t]{3}{*}{ Disadvantages } & $\begin{array}{l}\text { Requires parenteral } \\
\text { infusion }\end{array}$ & $\begin{array}{l}\text { May not achieve negative } \\
\text { iron balance in all } \\
\text { patients at } 75 \mathrm{mg} / \mathrm{kg} \\
\text { per day }\end{array}$ & Limited long-term data \\
\hline & $\begin{array}{l}\text { Ear, eye, bone } \\
\text { toxicity }\end{array}$ & Risk of agranulocytosis & Need to monitor renal function \\
\hline & Poor compliance & & $\begin{array}{l}\text { May not achieve negative } \\
\text { iron balance in all patients } \\
\text { at highest dose }\end{array}$ \\
\hline
\end{tabular}

Acknowledgements The author wants to acknowledge the valuable help of B. Turlin, Pathology Department, University Hospital of Rennes, France, for illustrating iron overload in a liver biopsy; J. Wood, Divisions of Pediatric Cardiology and Radiology, Children's Hospital Los Angeles, Los Angeles, CA, USA, for MRI images, and A. Cohen, Children's Hospital of Philadelphia, Philadelphia, PA, USA for permission to use and adapt a table.

\section{References}

1. Borgna-Pignatti C, Cappellini MD, De Stefano P, Del Vecchio GC, Forni GL, Gamberini MR, Ghilardi R, Piga A, Romeo MA, Zhao H, Cnaan A (2006) Cardiac morbidity and mortality in deferoxamine or deferiprone-treated patients with thalassemia major. Blood 107:3733-3737
2. Cappellini MD (2005) Iron-chelating therapy with the new oral agent ICL670 (Exjade $\left.{ }^{\circledR}\right)$. Best Pract Res Clin Haematol 18: 289-298

3. Cappellini MD, Cohen A, Piga A, Bejaoui M, Perrotta S, Agaoglu L, Aydinok Y, Kattamis A, Kilinc Y, Porter J, Capra M, Galanello R, Fattoum S, Drelichman G, Magnano C, Verissimo M, Athanassiou-Metaxa M, Giardina P, Kourakli-Symeonidis A, Janka-Schaub G, Coates T, Vermylen C, Olivieri N, Thuret I, Opitz H, Ressayre-Djaffer C, Marks P, Alberti D (2006) A phase 3 study of deferasirox (ICL670), a once daily oral iron chelator, in patients with beta thalassemia. Blood 107:3455-3462

4. Cohen AR (2006) New advances in iron chelation therapy. http:// www.asheducationbook.org Hematology 2006 42-47

5. Delea TE, Sofrygin O, Thomas SK, Baladi JF, Phatak PD, Coates $\mathrm{T}$ (2007) Cost effectiveness of once-daily oral chelation therapy with Deferasirox versus infusional Deferoxamine in transfusiondependent thalassaemia patients. Pharmacoeconomics 25:329-342 
6. Fischer R, Piga A, Harmatz P, Nielsen P (2005) Monitoring longterm efficacy of iron chelation treatment with biomagnetic liver susceptometry. Ann N Y Acad Sci 1054:350-357

7. Glickstein H, Ben El R, Shvartsman M, Cabantchik I (2005) Intracellular labile iron pools as direct targets of iron chelators : a fluorescence study of chelator action in living cells. Blood 106:3242-3250

8. Guyader D, Thirouard AS, Erdtmann L, Rakba N, Jacquelinet S, Danielou H, Perrin M, Jouanolle AM, Brissot P, Deugnier Y (2007) Liver iron is a surrogate marker of severe fibrosis in chronic hepatitis C. J Hepatol 46:587-595

9. Kattamis A, Ladis V, Berdousi H, Kelekis NL, Alexopoulou E, Papasotiriou I, drakaki K, Kaloumenou I, Galani A, Kattamis C (2006) Iron chelation treatment with combined therapy with deferiprone and deferioxamine : a 12-month trial. Blood Cell Mol Dis 36:21-25

10. Kontoghiorghes GJ (2006) New chelation therapies and emerging chelating drugs for the treatment of iron overload. Expert Opin Emerging Drugs 11:1-5

11. Pennell DJ, Berdoukas V, Karagiorga M, Ladis V, Piga A, Aessopos A, Gotsis ED, tanner MA, Smith GC, Westwood MA, Wonke B, Galanello R (2006) Randomized controlled trial of deferiprone or deferoxamine in beta-thalassemia major patients with asymptomatic myocardial siderosis. Blood 107:3738-3744

12. Stumpf JL (2007) Deferasirox. Am J Health-Syst Pharm 64: 606-616

13. Wood JC (2007) Magnetic resonance imaging measurement of iron overload. Curr Opin Hematol 14(3):183-190 